\title{
SIFAT DAN KUALITAS PENGERINGAN LIMA JENIS KAYU DARI KEBUN RAYA BOGOR
}

\author{
(The Properties and Drying Quality of Five Wood Species \\ from Bogor Botanical Garden)
}

\author{
Oleh/By: \\ Efrida Basri ${ }^{1)}$, Sri Rulliaty ${ }^{1)}$ \& Saefudin $^{2)}$
}

\begin{abstract}
The research was conducted to observe the quality of five dried wood and its relationship with their anatomical and physical properties. The wood which were collected from Bogor Botanical Garden collection that fell in June 2006 i.e. bayur (Pterospermum celebicum Miq.), belangeran (Shorea belangeran (Korth.) Burck), kayu darab (Myristica celebica (Mill.) W.J.de Wilde), membacang (Mangifera altissima Blanco) and ulin (Eusyderoxylon zwagery Teijsm \& Binn). The drying quality was investigated using quick drying method at bigh temperature $\left(100^{\circ} \mathrm{C}\right)$. The wood properties observed were physical and anatomical properties.

The results indicated that the drying quality was affected by wood anatomical structures as well as by its physical properties. Shrinkage level was found higher on wood with bigh specific gravity than on those with low specific gravity. Therefore, high-specific gravity wood was easier to get honeycomb during drying process. Some anatomical properties, such as fiber direction, parenchyma types, ray cells dimension and types, vessel sizes and the presence of tyloses or amorf crystallites inside vessel, played an important role during drying process. Bayur and membacang were found having the best drying quality, among the five wood species, while ulin was on the other way around.
\end{abstract}

Keywords: Anatomical properties, physical properties, drying quality, Bogor Botanical Garden wood

\begin{abstract}
ABSTRAK
Tujuan penelitian adalah untuk mengetahui kualitas pengeringan lima jenis kayu koleksi Kebun Raya Bogor yang tumbang pada bulan Juni 2006 serta mengaitkannya dengan sifat fisis dan anatomis kayu tersebut. Kelima jenis kayu tersebut adalah bayur (Pterospermum celebicum Miq.), belangeran (Shorea belangeran (Korth.) Burck), kayu darah (Myristica celebica (Mill.) W.J.de Wilde), membacang (Mangifera altissima Blanco) dan ulin (Eusyderoxylon zwagery Teijsm \& Binn). Pengujian sifat kayu meliputi sifat fisis dan anatomi kayu. Pengujian kualitas pengeringan dilakukan menggunakan metode pengeringan suhu tinggi (suhu $100^{\circ} \mathrm{C}$ ).

Hasil penelitian menunjukkan kualitas pengeringan kayu ditentukan oleh sifat fisik dan anatomi kayu. Kayu yang mempunyai berat jenis tinggi memiliki tingkat penyusutan lebih besar dibandingkan dengan kayu yang mempunyai berat jenis rendah, sehingga mudah mengalami pecah dalam pada waktu dikeringkan. Sifat anatomi yang berperan pada waktu kayu dikeringkan antara lain arah serat, bentuk parenkim, bentuk dan lebar jari-jari, ukuran pori dan ada atau tidaknya tilosis atau endapan amorf dalam pembuluh. Dari kelima jenis kayu yang diteliti, kualitas pengeringan terbaik diperoleh pada kayu bayur dan membacang sedangkan kualitas pengeringan terburuk terdapat pada kayu ulin.
\end{abstract}

Kata kunci: Sifat anatomi, sifat fisis, kualitas pengeringan, kayu Kebun Raya Bogor.

\footnotetext{
${ }^{1)}$ Peneliti pada Pusat Litbang Hasil Hutan
}

${ }^{27}$ Peneliti pada Pusat Penelitian Biologi - LPI 


\section{PENDAHULUAN}

Kebun Raya Bogor yang didirikan oleh Casper Georg Carl Reinwardt seorang ilmuwan Jerman-Amsterdam pada tahun 1817, merupakan lembaga ilmiah yang bernaung di bawah Lembaga Ilmu Pengetahuan Indonesia (LIPI), memiliki peran sangat penting dalam mengoleksi keanekaragaman tumbuhan berkayu dari seluruh dunia (Astuti et al., 2001). Namun pada awal Juni 2006, sekitar 200 koleksi pohon berkayu Kebun Raya Bogor tumbang atau patah akibat diterjang hujan badai (Susetyo, 2006). Kebanyakan usia pohon tersebut sudah di atas 40 tahun, bahkan ada yang lebih dari 100 tahun.

Untuk mengetahui nilai produk dari kayu tersebut maka perlu didukung dengan data kualitas pengolahannya. Sebagaimana diketahui pengeringan merupakan salah satu kegiatan penting dalam pengolahan kayu karena berhubungan dengan peningkatan kualitas fisik kayu tersebut. Sedangkan tidak semua jenis kayu mudah dikeringkan, dalam pengertian bila pengeringannya tidak dilakukan secara hati-hati akan mengalami kerusakan fisik antara lain retak, pecah dan berubah bentuk. Hal ini karena setiap jenis kayu memiliki keragaman struktur anatomi, sifat fisis dan komponen zat ekstraktif, sehingga ketika dikeringkan memberikan respon yang berbeda (Bramhall dan Wellwood, 1976; Perre, 2001). Pengaruh kandungan kimia kayu terhadap kualitas pengeringan biasanya dianggap tidak begitu signifikan dibandingkan dengan pengaruh struktur anatomi dan sifat fisis kayu. Namun ada komponen ekstraktif yang mempengaruhi degradasi warna dan atau cacat kolap (collapse) pada jenis kayu tertentu sewaktu dikeringkan, antara lain pada kayu eukaliptus (Chafe, 1990), oak (Charrier dan Halluk, 1992), jati (Basri et al., 2004) dan mangium (Basri, 2005). Oleh karena itu pengaturan suhu dan kelembaban pada waktu pengeringan harus memperhatikan sifat-sifat kayu agar menguntungkan dari segi waktu, biaya dan kualitas produk.

Tujuan penelitian adalah untuk mengetahui kualitas pengeringan lima jenis kayu koleksi Kebun Raya Bogor yang tumbang pada bulan Juni 2006 serta mengaitkannya dengan sifat fisis dan anatomi kayu tersebut .

\section{BAHAN DAN METODE}

\section{A. Bahan dan Alat}

Bahan yang digunakan yaitu lima jenis kayu yang berasal dari Kebun Raya Bogor, merupakan kayu yang berasal dari bagian batang pohon yang tumbang. Spesifikasi kelima jenis kayu yang diteliti dapat dilihat pada Tabel 1.

Peralatan yang digunakan antara lain chainsaw, dial caliper, mikrotom, mikroskop, loupe, timbangan, dan oven. 
Tabel1. Spesifikasi kayu yang diteliti Table 1. Specification of wood investigated

\begin{tabular}{|c|c|c|c|c|}
\hline $\begin{array}{c}\text { Nama } \\
\text { perdagangan } \\
\text { (Commercial } \\
\text { name) }\end{array}$ & Jenis kay u (Wood species) & $\begin{array}{l}\text { Asal bibit } \\
\text { (Seed origin) }\end{array}$ & $\begin{array}{c}\text { Umur, } \\
\text { tahun } \\
\text { (Age, year) }\end{array}$ & $\begin{array}{l}\text { Diameter, } \\
(\text { Diameter }) \mathrm{cm}\end{array}$ \\
\hline 1. Bayur & Pterospermum celebicum Miq. & Maluku & 36 & 44 \\
\hline 2. Belangeran & $\begin{array}{l}\text { Shorea belangeran (Korth.) } \\
\text { Burck. }\end{array}$ & Bangka & $>77$ & 62 \\
\hline 3. Kayu darah & $\begin{array}{l}\text { Myristica celebica (Mill.) } \\
\text { W.J.de Wilde. }\end{array}$ & Philipina & 41 & 45 \\
\hline 4. Membacang & Mangifera altissima Blanco. & Thailand & 46 & 49 \\
\hline 5. Ulin & $\begin{array}{l}\text { Eusyderoxylon zwagery } \\
\text { Teijsm \& Binn. }\end{array}$ & Kalimantan & $>137$ & 90 \\
\hline
\end{tabular}

\section{A. Metode}

Pembuatan contoh uji dan pengujian sifat fisis kayu (penyusutan dan BJ kering udara) mengikuti ASTM D143-94 (Anonim, 1994). Namun sebagian data BJ kayu diambil dari Oey Djoen Seng (1990). Pembuatan preparat dilakukan menurut metoda Sass (1958). Ciri anatomi kayu diamati berdasarkan ciri-ciri yang telah dianjurkan oleh International Association of Wood Anatomist Committee (IAWA) (Wheeler et al., 1989).

Kualitas pengeringan ditetapkan berdasarkan karakter kayu bila diberi suhu tinggi secara terus menerus sampai kayu tersebut mencapai tingkat kekeringan $0 \%$. Untuk keperluan tersebut, setiap jenis kayu dibuat contoh uji dari papan tangensial dengan ukuran $2,0 \mathrm{~cm} \times 10 \mathrm{~cm} \times 2,0 \mathrm{~cm}$ untuk pengukuran kadar air dan $2,0 \mathrm{~cm} \times 10 \mathrm{~cm} \times 20 \mathrm{~cm}$ untuk pengujian kualitas pengeringan. Percobaan dilakukan dengan cara mengeringkan contoh uji dalam oven pada suhu konstan $100{ }^{\circ} \mathrm{C}$ dan diamati perubahan kualitasnya secara periodik hingga contoh uji mencapai kadar air kering oven (kadar air 0\%). Penilaian kualitas kayu didasarkan pada kehadiran tiga jenis cacat dan tingkat kerusakan berdasarkan metode Terazawa (1965) yang telah dimodifikasi (Tabel 2 - 4). Berdasarkan klasifikasi kualitas pengeringan, kemudian ditetapkan kisaran suhu untuk masing-masing jenis kayu. 
Tabel 2. Persentase cacat retak/pecah ujung dan/atau permukaan pada contoh uji kayu dan klasifikasi sifat pengeringan

Table 2. Percentage of end and/or surface checks in wood sample and drying property classification

\begin{tabular}{|c|c|c|}
\hline $\begin{array}{c}\text { Nilai cacat (Defect } \\
\text { value) } \%\end{array}$ & $\begin{array}{c}\text { Kelas } \\
(\text { Class })\end{array}$ & \begin{tabular}{c} 
Sifat pengeringan (Drying property) \\
\hline $0-5$
\end{tabular} \\
\hline$>5-10$. & I & Sangat baik (Very good) \\
\hline$>10-20$ & III & Agak baik (Rather good) \\
\hline$>20-30$ & IV & Sedang (Fair) \\
\hline$>30-50$ & V & Agak buruk (Rather poor) \\
\hline$>50-70$ & VI & Baruk (Poor) \\
\hline$>70$ & VII & Sangat buruk (Very poor) \\
\hline
\end{tabular}

Sumber (Source) : Terazawa (1965)

Tabel3. Perbedaan 2 ukuran tebal (cacat deformasi) pada arah radial contoh uji kayu dan klasifikasi sifat pengeringan

Table 3. Difference of two thickness (deformation check) in radial direction of wood sample and drying property classification

\begin{tabular}{|c|c|c|}
\hline $\begin{array}{c}\text { Perbedaan } 2 \text { ukuran tebal (Two } \\
\text { tickness difference), mm }\end{array}$ & $\begin{array}{l}\text { Kelas } \\
\text { (Class) }\end{array}$ & Sifat pengeringan (Drying property) \\
\hline $0-0,3$ & I & Sangat baik ( Very good) \\
\hline $0,3-0,6$ & II & Baik ( Good) \\
\hline $0,6-1,2$ & III & Agak baik ( Rather good) \\
\hline $1,2-1,8$ & IV & Sedang (Fair) \\
\hline $1,8-2,5$ & V & Agak buruk (Rather poor) \\
\hline $2,5-3,5$ & VI & Buruk (Poor) \\
\hline$>3,5$ & VII & Sang at buruk (Very poor) \\
\hline
\end{tabular}

Sumber (Source) : Terazawa (1965) 
Tabel 4. Jumlah cacat pecah pada bagian dalam contoh uji kayu dan klasifikasi sifat pengeringan

Table 4. Total defect of boneycombing checks in wood sample and drying property classification

\begin{tabular}{|l|c|c|}
\hline \multicolumn{1}{|c|}{ Jumla h cacat (Defect total ) } & $\begin{array}{c}\text { Kelas } \\
(\text { Class })\end{array}$ & $\begin{array}{c}\text { Sifat pengeringan (Drying } \\
\text { property) }\end{array}$ \\
\hline 0 & I & Sangat baik (Very good) \\
\hline 1 besar (major) atau/or 2 kecil (minors) & II & Baik (Good) \\
\hline 2 besar (majors) atau/or $4-5$ kecil (minors) & III & Agak baik (Rather good) \\
\hline 4 besar (majors) atau/or $7-9$ kecil (minors) & IV & Sedang (Fair) \\
\hline $6-8$ besar (majors) atau/or 15 kecil (minors) & V & Buruk (Poor) \\
\hline 17 besar (majors) atau/or kecil (minors) & VI & Sangat buruk (Very poor) \\
\hline
\end{tabular}

Sumber (Source) : Terazawa (1965)

\section{HASIL DAN PEMBAHASAN}

Data sifat fisik dan kualitas pengeringan kelima jenis kayu yang diteliti dapat dilihat dalam Tabel 5 dan 6. Hasil pengamatan terhadap kelima jenis kayu yang diteliti menunjukkan kualitas pengeringan kayu ditentukan oleh faktor fisis dan anatomi kayu tersebut. BJ kayu yang tinggi memiliki tingkat penyusutan lebih besar dibandingkan dengan BJ kayu yang rendah (Tabel 5) karena air terikat yang dikeluarkan dari dinding sel lebih banyak, sehingga berpengaruh pada waktu dan besarnya penyusutan kayu. Namun demikian, kayu yang ber-BJ tinggi proses penguapan airnya akan berjalan lancar asalkan struktur kayunya mendukung, seperti memiliki arah serat yang lurus dan ukuran pori yang besar serta tidak ada sumbatan berupa tilosis atau endapan-endapan amorf (Siau, 1971). Dari Tabel 5 juga tampak terdapat hubungan antara berat jenis (BJ) dan kadar air kayu segar pada pohon yang baru ditebang. Semakin tinggi BJ, semakin berkurang kandungan air dalam kayu tersebut karena rongga selnya makin sedikit. 
Tabel 5. Sifat fisis 5 jenis kayu yang diteliti

Table 5. Physical properties of 5 wood species investigated

\begin{tabular}{|c|c|c|c|c|c|c|c|}
\hline \multirow{3}{*}{$\begin{array}{l}\text { Jenis kayu } \\
\text { (Wood species) }\end{array}$} & \multirow{3}{*}{$\begin{array}{c}\text { Berat } \\
\text { jenis } \\
\text { (Specific } \\
\text { gravity) }\end{array}$} & \multirow{3}{*}{$\begin{array}{c}\text { Kadar } \\
\text { air segar } \\
\text { (Green } \\
\text { moisture } \\
\text { content), } \\
\%\end{array}$} & \multicolumn{4}{|c|}{ Penyusutan (Shrinkage ), \% } & \multirow[b]{3}{*}{$\mathrm{T} / \mathrm{R}$} \\
\hline & & & \multicolumn{2}{|c|}{$\mathrm{BS}-\mathrm{KU}$} & \multicolumn{2}{|c|}{$\mathrm{BS}-\mathrm{KT}$} & \\
\hline & & & $\mathrm{R}$ & $\mathrm{T}$ & $\mathrm{R}$ & $\mathrm{T}$ & \\
\hline 1. Bayur & 0,46 & 123 & 1,79 & 3,48 & 3,00 & 5,75 & $<2$ \\
\hline 2. Belangeran & $0,86^{1}$ & 70 & - & - & - & - & - \\
\hline 3. Kayu darah & $0,54^{1}$ & 105 & 1,81 & 3,86 & 3,01 & 6,50 & $>2$ \\
\hline 4. Membacang & 0,64 & 79 & 1,95 & 3,92 & 3,32 & 6,65 & 2 \\
\hline 5. Ulin & $1,04^{1}$ & 56 & - & - & $4,2^{2}$ & $8,3^{2}$ & 2 \\
\hline
\end{tabular}

Sumber (Sources): ${ }^{1)}$ Oey Djoen Seng (1990); ${ }^{2)}$ Martawijaya dkk. (2005)

Keterangan (Remarks): BS -KU = Basah ke kering udara (Green to air dry); BS-KT = Basah ke kering $\operatorname{tanur}($ Green to oven $d r y) ; \mathrm{R}=$ Radial; $\mathrm{T}=$ Tangensial (Tangential)

Tabel 6. Kualitas pengeringan 5 jenis kayu yang diteliti

Table 6. Drying qualities of 5 wood species investigated

\begin{tabular}{|c|c|c|c|c|c|}
\hline \multirow[t]{2}{*}{$\begin{array}{l}\text { Jenis kayu } \\
\text { (Wood species) }\end{array}$} & \multirow[t]{2}{*}{$\begin{array}{l}\text { Kadar air segar } \\
\text { (Green moisture } \\
\text { content ), } \%\end{array}$} & \multicolumn{3}{|c|}{$\begin{array}{l}\text { Jenis cacat dan kelas } \\
\text { kerusakan (Defect variety } \\
\text { and class) }\end{array}$} & \multirow{2}{*}{$\begin{array}{c}\text { Kualitas } \\
\text { pengeringan } \\
\text { (Drying } \\
\text { Quality) }\end{array}$} \\
\hline & & A & B & $\mathrm{C}$ & \\
\hline 1. Bayur & 123 & II & II & I & $\mathrm{b}$ \\
\hline 2. Belangeran & 70 & II-III & III & II & $\mathrm{c}$ \\
\hline 3. Kayu darah & 105 & II & III-IV & I & d \\
\hline 4. Membacang & 79 & II & II & I & $\mathrm{b}$ \\
\hline 5. Ulin & 56 & VII & I & V-VI & g \\
\hline
\end{tabular}

Keterangan (Remarks): A. Retak/pecah ujung dan permukaan (End and surface cheks); B. Perubahan bentuk/deformasi (Deformation); C. Pecah dalam (Honeycomb); a. Sangat baik (Very good); b. Baik (Good); c. Agak baik (Rathergood); d. Sedang (Fair); e. Agak buruk (Ratherpoor); f. Buruk (Poor); g. Sangat buruk (Verypoor) 
Pada ulin BJ berpengaruh terhadap kualitas pengeringan kayu tersebut. Ulin yang memiliki BJ di atas 1 (Kelas kuat I), meskipun perbedaan penyusutan pada arah tangensial terhadap arah radial kayunya hanya sekitar 2 yang menunjukkan kayu tersebut sebenarnya cukup stabil, namun kualitas pengeringannya sangat buruk yaitu mengalami retak dan pecah di bagian permukaan dan pecah dalam seperti juga dilaporkan dalam Martawijaya (1989). Faktor yang menyebabkan permeabilitas sel kayu ulin sangat rendah karena selain dinding sel kayunya sangat tebal yang mengindikasikan akan lebih banyak air yang terikat dalam gugus hydroxyl, juga memiliki jari-jari yang sempit berisi endapan serta dalam pori terdapat tilosis dan endapan. Selain itu faktor umur pohon ( $>137$ tahun) juga sangat berpengaruh, semakin banyak lignin pada dinding sel akan mengurangi permeabilitas kayu (Siau, 1971). Semua faktor tersebut sangat menghambat proses pengeluaran air dari dalam kayu. Ketika proses pengeringan kayu ulin dipercepat, dinding sel kayu tersebut akan tertarik oleh daya kapiler air. Jika tegangan penyusutan melebihi kekuatan kayu yang tegak lurus pada arah seratnya maka terjadilah pecah permukaan yang berlanjut sampai ke bagian dalam kayu (Bramhall dan Wellwood 1976; Wang et al., 1994 ; Reeb, 2007). Yang perlu diperhatikan, pada awal pengeringan kayu ulin sebaiknya hanya menggunakan suhu kamar yang dibantu dengan sirkulasi udara. Setelah kadar air kayu tersebut mendekati titik jenuh serat baru diberikan perlakuan suhu.

Kayu belangeran meskipun memiliki BJ cukup tinggi (Kelas kuat II-I), namun agak mudah dikeringkan. Faktor utama yang mendukung kayu tersebut cukup mudah dikeringkan karena memiliki pori yang lebih besar dibandingkan kayu ulin, jari-jari yang lebih lebar (umumnya multiseriat) dan tinggi, sel parenkim yang berbentuk pita dan aliform. Struktur anatomi kayu yang demikian menurut Panshin dan de Zeeuw (1969) dan Siau (1971) membantu proses pengeluaran air dari dalam kayu. Namun yang harus diperhatikan pada pengeringan kayu belangeran, adanya kecenderungan mengalami cacat bentuk pada arah memanjang kayu (cacat membusur) jika penumpukannya tidak dilakukan secara benar karena saluran interseluler kayu tersebut pada arah longitudinal kayu seringkali berisi damar yang tentunya akan menimbulkan tegangan pengeringan pada arah tersebut.

Kayu darah meskipun memiliki BJ lebih rendah dari kayu belangeran, namun kualitas pengeringannya lebih rendah dibandingkan kayu belangeran. Kayu ini memiliki arah serat yang berpadu, terdapat tilosis pada pembuluh, noktah pada pembuluh tidak besar, jari-jarinya termasuk sempit, dan walaupun memiliki parenkim pita tapi jarang dan sempit, faktor-faktor tersebut akan mempengaruhi kecepatan keluarnya air dari dalam kayu. Terhadap kayu yang memiliki tilosis dan atau damar dalam pembuluh, seperti yang ditemukan pada kayu belangeran dan darah, sebaiknya diberikan perlakuan pengukusan (steam treatment) sebelum dilakukan proses pengeringan

Kayu bayur dan membacang memiliki kualitas pengeringan terbaik diantara kelima jenis yang diteliti. Hal ini juga ditunjukkan dari rasio penyusutan arah tangensial terhadap arah radialnya kurang dari 2. Faktor dalam kayu yang membantu proses pengeringan kayu bayur adalah BJ-nya termasuk sedang dengan dinding serat yang lebih tipis bila dibandingkan kayu lainnya yang diamati, ukuran pori agak besar, serta parenkim berbentuk pita dan agak rapat.

Struktur anatomi kayu membacang sangat mendukung proses keluarnya air dari dalam kayu karena kayu tersebut memiliki arah serat yang lurus, pori dan noktah antar pembuluh lebih besar, dinding serat tipis, parenkim berbentuk pita, sayap dan konfluen. 
Kayu yang peka terhadap cacat pecah dalam (honeycombing defect), yaitu yang memiliki tingkat penyusutan tinggi di awal pengeringan maka harus menggunakan suhu yang lunak. Keadaan ini tetap dipertahankan sampai air yang tinggal dalam kayu hanya berisi air terikat (kadar air $\leq 30 \%$ ). Hal ini karena pecah pada bagian dalam kayu dan cacat kolap hanya berlangsung ketika air masih ada dalam rongga sel, semakin basah kayu semakin tinggi tingkat cacatnya (Rasmussen, 1968; Kobayashi, 1986). Keadaan yang demikian juga terjadi pada kayu mangium. Kayu mangium yang kadar airnya masih di atas 30\% ketika dikeringkan menggunakan suhu $60^{\circ} \mathrm{C}$ tampak mengalami pecah dalam sementara hal tersebut tidak terjadi pada kayu yang kadar airnya sudah mendekati titik jenuh serat (Basri dan Hayashi, 1999).

Berdasarkan kualitas pengeringan tersebut, maka mengacu pada standar yang dibuat oleh Shin Terazawa (1965) kayu bayur dan membacang bisa dikeringkan menggunakan suhu $65^{\circ} \mathrm{C}-90^{\circ} \mathrm{C}$ tanpa mengalami cacat. Sedangkan kayu ulin hanya bisa dikeringkan menggunakan suhu yang lunak, yaitu pada kisaran $45^{\circ} \mathrm{C}-70^{\circ} \mathrm{C}$. Adapun kisaran suhu pengeringan untuk kayu belangeran adalah $55^{\circ} \mathrm{C}-83^{\circ} \mathrm{C}$ dan kayu darah $50^{\circ} \mathrm{C}-80^{\circ} \mathrm{C}$. Kisaran suhu hasil percobaan tersebut dalam penerapannya perlu dimodifikasi lagi dan disesuaikan dengan tipe, kapasitas dan kondisi dapur pengering, ukuran dan kualitas kayu serta kadar air sebelum pengeringan. Oleh karena itu keberhasilan dalam penerapannya sangat bergantung pada operator.

\section{KESIMPULAN DAN SARAN}

1. Terdapat hubungan yang erat antara faktor fisis dan anatomis dengan kualitas pengeringan kayu.

2. Kayu yang mempunyai Berat Jenis tinggi memiliki kadar air kayu segar lebih rendah namun tingkat penyusutan karena pengeringan lebih besar dibandingkan dengan kayu ber-Berat Jenis rendah.

3. Kayu yang memiliki arah serat lurus, parenkimnya berbentuk pita, jari-jari lebar serta ukuran pori yang besar dan tidak ada sumbatan di dalamnya sangat membantu dalam proses pengeringan kayu.

4. Berdasarkan hasil pengujian kualitas pengeringan lima jenis kayu, maka kisaran suhu yang sesuai untuk kayu bayur dan membacang $65-90^{\circ} \mathrm{C}$; kayu belangeran 55 - $83^{\circ} \mathrm{C}$; kayu darah $50-80^{\circ} \mathrm{C}$ dan kayu ulin $45-70^{\circ} \mathrm{C}$.

4. Dalam penerapan pada skala industri, kisaran suhu dan kelembaban hasil percobaan tersebut disarankan untuk dimodifikasi lagi dan disesuaikan dengan tipe, kapasitas dan kondisi dapur pengering, ukuran dan kualitas kayu, kadar air sebelum pengeringan dan pengalaman operator. 


\section{DAFTAR PUSTAKA}

Anonim. 1994. Standard methods of testing small clear specimens of timber. In Annual Book of ASTM Standard Vol. 4, Sec. 4. Construction. Philadelphia.

Astuti, I.P., L.P. Soewilo, T.D. Said dan R.N.A. Kosasih. 2001. An alphabetical list of plant species cultivated in the Bogor Botanical Garden. CV. Riza Graha Jaya Bogor. pp. 9

Basri, E. dan K. Hayashi. 1999. Percobaan pembuatan bagan pengeringan kayu mangium di Laboratorium Pengeringan Kayu, Ehime University. Matsuyama, Japan (manuskrip).

Basri, E. 2005. Mutu kayu mangium dalam beberapa metode pengeringan. Jurnal Penelitian Hasil Hutan Vol. 23 (2): 119 -129. Pusat Litbang Hasil Hutan. Bogor.

Basri, E., D. Rohadi, T. Priadi dan I. Wahyudi. 2004. The alleviation of discoloration in teak (Tectona grandis L.f.) wood through drying and chemical treatments. Jurnal IPTEK Kayu Tropis Vol. 2 (1): 57-61. Masyarakat Peneliti Kayu Indonesia. Bogor.

Bramhall, G. dan R.W. Wellwood. 1976. Kiln drying of western Canadian lumber. Cana- dian Forestry Service. Western Forest Products Laboratory. Vancouver, British Columbia.

Chafe, S.C. 1990. Effect of brief presteaming on shrinkage, collapse and other wood-water relationships in Eucalyptus regnans F. Muell. Wood Sci. Technology 24: 311-326. Berlin.

Charrier, B. dan J.P. Haluk. 1992. Prevention of brown discoloration in European Oak wood occurring during kiln drying by a vacuum process: Colorimetric comparative study with a traditional process. Holz als Roh-und Werkstoff 50: 433-437.

Kobayashi, Y. 1986. Cause of collapse in western red-cedar. Mokuzai Gakkaishi 32 (10): 846847. Japanese Wood Researcher Society. Tokyo.

Martawijaya, A., I. Kartasujana, K. Kadir dan S.A. Prawira. 2005. Atlas kayu Indonesia Jilid II: 91-95. Badan Penelitian dan Pengembangan Kehutanan, Departemen Kehutanan. Bogor. Edisi revisi.

Oey Djoen Seng. 1990. Berat jenis kayu Indonesia dan pengertian beratnya kayu untuk keperluan praktek. Pengumuman No. 11, Lembaga Penelitian Hasil Hutan. Bogor. Cetak ulang.

Panshin, A.J. dan C. De Zeeuw. 1969. Text book of wood technology, 3 rd. McGraw-Hill Book Co. New York. pp 150-197.

Perre, Patrick. 2001. The drying of wood: the benefit of fundamental research to shift from improvement to innovation. Proceeding Of the $7^{\text {th }}$ International IUFRO Wood Drying Conference July 9-13, 2001. Tsukuba, Japan. pp. 2 - 13.

Rasmussen, E.F. 1961. Dry Kiln Operator's Manual. U.S. Department of Agriculture. Agric. Handbook 188 
Reeb, J.E.. 2007. Drying wood. Website: http://www.ca.uky.edu/agc/pubs/for/ for55/for55.htm. Diakses pada tanggal 13 Februari 2007.

Sass, J.E. 1958. Botanical Microtechnique. $3^{\text {rd }}$. The Iowa Univ. Press, Ames. Iowa.

Siau, J.F. 1971. Flow in wood. Syracuse Univ. Press. New York. pp. 1 - 67.

Susetyo, S.B. 2006. Kebun Raya Bogor (KRB) rusak berat. Harian Kompas terbitan 3 Juni 2006. PT Gramedia. Jakarta.

Terazawa, S. 1965. An easy methods for the determination of wood drying schedule. Wood Industry Vol. 20 (5), Wood Technological Association of Japan.

Wang, Z., E.T. Choong dan V.K. Gopu. 1994. Effect of presteaming on drying stresses of red oak using a coating and bending method. Wood and Fiber Science 26 (4): 527 - 535.

Wheeler, E.a., P. Baas dan E. Gasson. 1989. IAWA list of microscopic features for hardwood identification. IAWA Bulletin. N.S. 10 (3): 219-332. 